\title{
Self-harm, anxiety, and depression in adolescents attending a public school in a city
}

\section{in southern Minas Gerais, Brazil}

\author{
Autolesão, ansiedadle e depressão em adolescentes de uma escola de um município do sul de Minas \\ Gerais, Brasil
}

Autolesiones, ansiedad y depresión en adolescentes de una escuela de un municipio del sur de Minas

Gerais, Brasil

Received: 02/09/2022 | Reviewed: 02/16/2022 | Accept: 02/23/2022 | Published: 03/04/2022

\author{
Mariane Inaraí Alves \\ ORCID: https://orcid.org/0000-0001-6792-1398 \\ Universidade Federal de Alfenas, Brazil \\ E-mail: mariane.alves@unifal-mg.edu.br \\ Adriana Olimpia Barbosa Felipe \\ ORCID: https://orcid.org/0000-0002-4491-5750 \\ Universidade Federal de Alfenas, Brazil \\ E-mail: adriana.felipe@unifal-mg.edu.br \\ Denis da Silva Moreira \\ ORCID: https://orcid.org/0000-0002-5055-5210 \\ Universidade Federal de Alfenas, Brazil \\ E-mail: denis.moreira@unifal-mg.edu.br
}

\begin{abstract}
Objective: The objective of this study was to identify the presence of self-harm behavior among adolescents, the methods and reasons for this behavior, and to assess the association with the sociodemographic, anxiety, and depression variables. Methodology: This is a quantitative, descriptive, cross-sectional study carried out with 73 adolescents attending a school in a city in southern Minas Gerais, Brazil. The data collection instruments used were the following: Characterization, Economic Classification, Functional Assessment of Self - Mutilation, Screen for Child Anxiety Related Emotional Disorders, and the Children's Depression Inventory. Results: Self-harm was evidenced in $84.9 \%$ of the participants, $72.6 \%$ presented anxiety symptoms, $50.6 \%$ presented depression symptoms, and $37.1 \%$ presented suicidal ideation. The methods used for self-harm were the following: poking wounds, hitting and biting oneself, and skin cutting. The main motivations were the following: to relieve feelings of emptiness or indifference, to cease negative feelings or sensations, and to feel relaxed. Self-harm is associated with the female gender, suicidal ideation, anxiety, and depression. Conclusion: It is concluded that self-harm is a risk factor for suicide and generates significant suffering interfering negatively in the lives of adolescents. The need for greater attention to the mental health of adolescents in the school context is highlighted.
\end{abstract}

Keywords: Nursing; Adolescent; Self-harm; Self-Injurious behavior; Mental health; Anxiety; Depression.

\section{Resumo}

Objetivo: O objetivo foi identificar a presença de autolesão entre os adolescentes, os métodos e motivos para esse comportamento e avaliar a associação com as variáveis sociodemográficas, ansiedade e depressão. Metodologia: Trata-se de uma pesquisa quantitativa, descritiva, transversal, realizada com 73 adolescentes de uma escola de um município do sul de Minas Gerais, Brasil. Instrumento de coleta de dados: Caracterização, Classificação Econômica, Functional Assessment of Self - Mutilation, Screen for Child Anxiety Related Emotional Disorders e o Children's Depression Inventory. Resultados: Evidenciou-se a autolesão em 84,9\% dos participantes, 72,6\% com sintomas de ansiedade e 50,6 \% com sintomas depressivos, 37,1\% apresentaram ideação suicida. Os métodos de autolesão foram: cutucar ferimentos, bater e morder em si mesmo e cortar a pele. Os principais motivos: aliviar a sensação de vazio ou indiferença, parar sentimentos ou sensações ruins e sentir-se relaxado. A autolesão está associada ao sexo feminino, ideação suicida, ansiedade e depressão. Conclusão: Conclui-se que a autolesão é um fator de risco para o suicídio e gera um sofrimento significativo interferindo negativamente na vida dos adolescentes. Destaca-se a necessidade de uma maior atenção à saúde mental dos adolescentes no contexto escolar.

Palavras-chave: Enfermagem; Adolescente; Autolesão; Comportamento autolesivo; Saúde mental; Ansiedade; Depressão. 


\section{Resumen}

Objetivo: El objetivo fue identificar la presencia de autolesiones entre adolescentes, los métodos y motivos de este comportamiento y evaluar la asociación con variables sociodemográficas, ansiedad y depresión. Metodología: Se trata de un estudio cuantitativo, descriptivo, transversal, realizado con 73 adolescentes de una escuela de un municipio del sur de Minas Gerais, Brasil. Instrumento de recolección de datos: Caracterización, Clasificación Económica, Evaluación Funcional de Automutilaciones, Tamizaje de Trastornos Emocionales Relacionados con la Ansiedad Infantil e Inventario de Depresión Infantil. Resultados: Se evidenció autolesión en 84,9\% de los participantes, 72,6\% con síntomas de ansiedad y 50,6\% con síntomas depresivos, 37,1\% con ideación suicida. Los métodos de autolesión eran: pincharse las heridas, golpearse y morderse, y cortarse la piel. Los principales motivos: aliviar la sensación de vacío o indiferencia, frenar malos sentimientos o sensaciones y sentirse relajado. Las autolesiones se asocian con el género femenino, la ideación suicida, la ansiedad y la depresión. Conclusión: Se concluye que la autolesión es un factor de riesgo para el suicidio y genera un sufrimiento significativo, interfiriendo negativamente en la vida de los adolescentes. Se destaca la necesidad de una mayor atención a la salud mental de los adolescentes en el contexto escolar.

Palabras clave: Enfermería; Adolescente; Auto lastimarse; Comportamiento auto agresivo; Salud mental; Ansiedad; Depresión.

\section{Introduction}

Self-harm is a significant issue in adolescence, and it is strongly related to attempts (Hooley et al., 2020) and death by suicide (Hawton et al., 2013). Approximately 40-60\% of people who die by suicide have performed self-harm previously, meaning that the risk of suicide is higher for those who exhibit self-harm behavior (Geulayov et al., 2019; Owens et al., 2002).

Non-suicidal self-harm can be characterized as an individual's repeated behavior of causing superficial injuries to their body without suicidal intent. It most often begins in early adolescence and can continue for several years (American Psychiatric Association, 2014; Fortes et al., 2017). It is a common practice, with a lifetime prevalence of 7.5 to $46.5 \%$ in adolescents (Cipriano et al., 2017). Evidence exists supporting that it is associated with a range of psychological issues: depression, anxiety, and post-traumatic stress disorder (Bentley et al., 2014).

The World Health Organization (WHO) includes self-harm in the context of self-inflicted violence, corresponding to the intentional use of actual or threatened physical force against oneself. The types of self-inflicted violence are the following: suicide attempts, suicide, and self-harm (World Health Organization, 2014). In 2016, the Practice manual for establishing and maintaining surveillance systems for suicide attempts and self-harm was released, which aims to establish and maintain surveillance systems for suicide attempts and self-harm (World Health Organization, 2016).

In this context, in April 2019, the National Policy for Self-harm and Suicide Prevention was established in Brazil, and within its objectives are the following: the promotion of mental health; the prevention of self-induced violence; the control of the determining and conditioning factors of mental health; the guarantee of access to psychosocial care for people in psychological distress, especially those with a history of suicidal ideation, self-harm, and suicide attempts. This policy also guides the compulsory notification of suspected or proven cases of self-harm violence by public and private health and educational establishments (Law nº. 13,819, April 26, 2019).

It is noteworthy that monitoring self-harm assists in detecting behavioral aspects that are important for suicide prevention and for planning and implementing alternative treatments (Hawton et al., 2015). It is complemented that only a limited number of studies have been published in Brazil investigating self-harm in adolescence (Fonseca et al., 2018) and it is a condition that warrants further studies to be carried out to be better understood (Hooley et al., 2020).

In this sense, studies addressing this issue can contribute to public health policies aimed at adolescents (Fonseca et al., 2018). Given the above, the objective of this study was to identify the presence of self-harm among adolescents, the methods and reasons for this behavior, and to assess the association with the sociodemographic, anxiety, and depression variables. 


\section{Methodology}

This was a descriptive, cross-sectional study, based on a quantitative methodological approach, carried out with 73 adolescents attending a public school in a city in southern Minas Gerais, Brazil.

The sampling was of the non-probability type, and it was used for convenience. The inclusion criteria were the following: age ranging from 12 to 18 years, being literate, and being regularly enrolled in school. The exclusion criterion was to present deficiencies in the interpretation process, reading, and visual acuity.

Data collection took place in October 2019, and five self-applicable instruments were used.

A sociodemographic questionnaire was used to characterize the adolescents (Tavares et al., 2004). The economic classification was based on the Brazilian Economic Classification Criteria, and according to their score, participants are classified into one of the following economic classes: A - 45 to 100 points; B1 - 38 to 44; B2 - 29 to 37; C1 -23 to 28; C2 - 27 to 17; D-E - 0 to 16 (Brazilian Association of Research Companies, 2016).

The Functional Assessment of Self-Mutilation (FASM) (Lloyd, 1997), translated and adapted to Brazilian Portuguese, was used to assess self-harm. The FASM is a self-report scale that examines the forms and means used, frequency, and reasons for self-harm behavior (Giusti, 2013) and considers self-harm behavior to be the practice of self-harm at least once in the last year (Lloyd, 1997).

To assess anxiety, the Screen for Child Anxiety Related Emotional Disorders (SCARED), translated and validated for use with the Brazilian population, consists of 38 items that assess anxiety in the population aged from 7 to 17 years. The cutoff point is 34 points, participants with scores equal to or higher present anxiety symptoms (Barbosa et al., 2002).

In the assessment of depression, the Children's Depression Inventory (CDI), translated and adapted for Brazilian socio-cultural characteristics (Gouveia et al., 1995), consists of 27 items and measures depressive symptomatology in children and adolescents aged from 7 to 17 years (Coutinho et al., 2014). The cut-off point is 17 points, and participants with scores equal to or higher present depressive symptomatology (Gouveia et al., 1995; Rodrigues-Palucci \& Loureiro, 2017).

Before starting data collection, the adolescents were informed of the study objectives and method and were given the Informed Consent Form for their signature. They were also asked to hand in the Informed Consent Form to their parents and guardians to authorize their participation in the study.

This study complied with Resolution 466/12 (National Health Council, 2013) and obtained approval with legal opinion number 3,509,507 from the Research Ethics Committee. Anonymity and confidentiality of the information provided by respondents were guaranteed.

For data analysis, the Bioestat software version 5.0 was used, based on descriptive statistics with distribution and frequency analysis, for the association between sociodemographic variables with self-harm the Fisher's exact test was used. To evaluate the probabilities the Odds Ratio test was used. In the association of self-harm with anxiety, the t-test for independent samples was used, and in the association with depression, the Mann-Whitney test was used. For the analysis of variance in the association of suicidal ideation with anxiety and depression, the Kruskal-Wallis test was used. The significance level was $5 \%$.

\section{Results}

Regarding the participants' characterization, most of them were female (64.4\%), aged 15 years on average, $68.5 \%$ were in high school, belonging to economic classes C1 and B2 (57.5\%), single (97.3\%), and not working (74\%).

Self-harm was presented by 84.9 percent of the participants, 72.6 percent presented anxiety symptoms, and 50.6 percent presented depression symptoms, 37.1 percent were thinking about committing suicide while they performed self-harm, 58 percent reported feeling little or no pain, and 91.9 percent were not under the influence of alcohol or other drugs. 
The most frequent methods of self-harm reported were the following: poking wounds, hitting and biting oneself, and skin cutting. The main motivations were the following: to relieve feelings of emptiness or indifference, to cease negative feelings or sensations, and to feel relaxed.

A statistically significant association was observed between the gender and self-harm variables by the Odds Ratio (OR). The female gender was nine times more likely to develop self-harm behavior, as presented in Table 1 .

Table 1 - Relationship between the sociodemographic variables and self-harm practiced by adolescents attending a school in a city in southern Minas Gerais, Brazil, 2021.

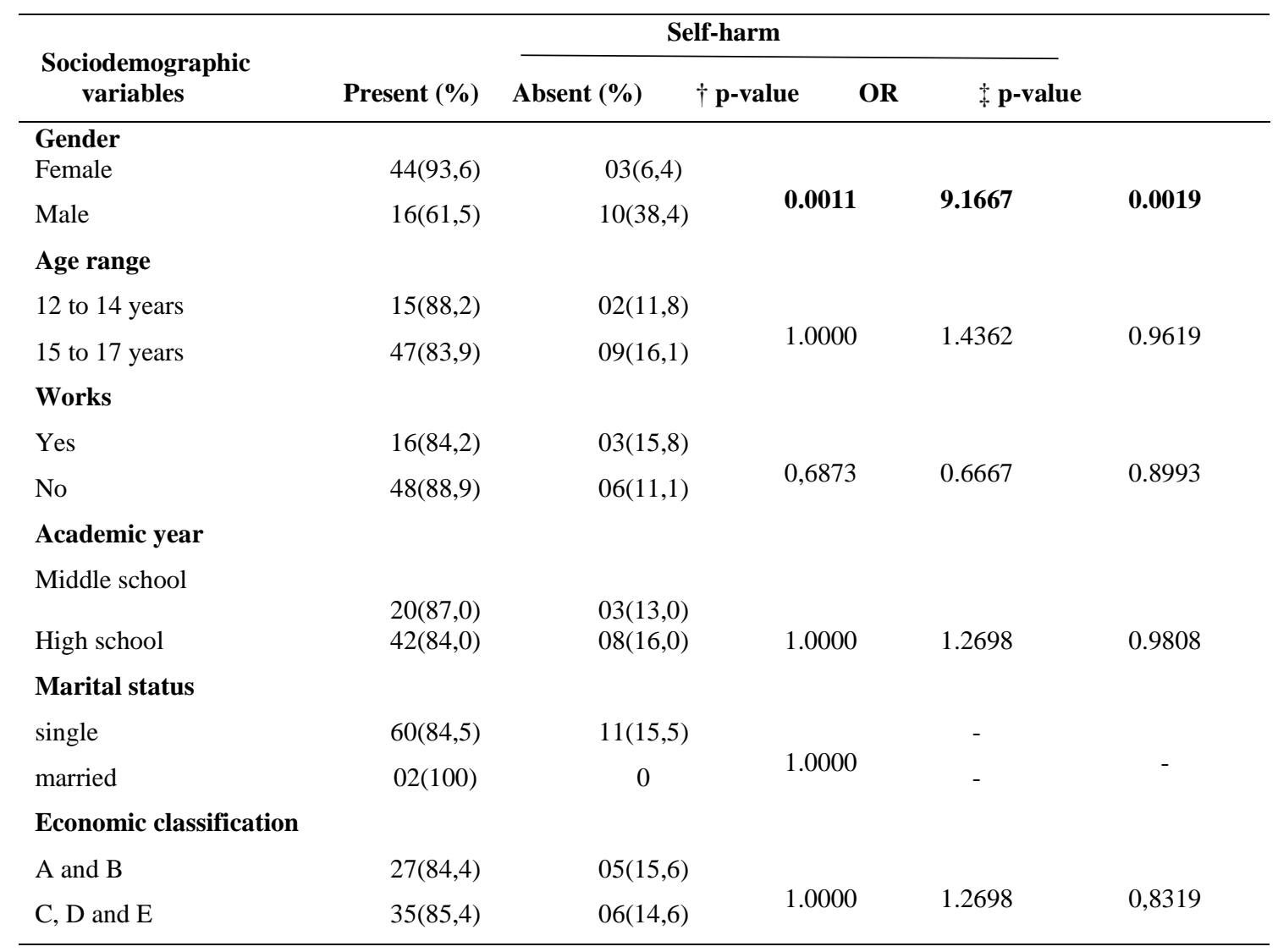

Note: $\mathrm{A}=$ upper class, $\mathrm{B}=$ upper-middle class, $\mathrm{C}=$ middle class, $\mathrm{D}=$ working class, $\mathrm{E}=$ lower class; $\dagger$ Fisher's Exact Test; $+\mathrm{OR}$ : Odds Ratio. Source: Authors (2021).

In Table 2, the analyses of self-harm association with anxiety and depression were presented, and there was a significant association with higher mean scores of the participants who practiced it.

Table 2 - Analysis of self-harm alongside anxiety and depression scores in adolescents attending a school in a city in southern Minas Gerais, Brazil, 2021.

\begin{tabular}{cccccccc}
\hline & \multicolumn{3}{c}{ Anxiety } & \multicolumn{3}{c}{ Depression } \\
\hline Self-harm & n & Mean & Median & $\boldsymbol{p}$-value & Mean & Median & $\boldsymbol{p}$-value \\
Present & 62 & 49,77 & 52,00 & $\mathbf{0 , 0 0 1 1 \dagger}$ & 18,97 & 18,00 & $\mathbf{0 , 0 0 0 1 \dagger}$ \\
Absent & 11 & 29,27 & 26,00 & & 7,36 & 5,00 & \\
\hline
\end{tabular}

Note: $p$ : significance level; $\uparrow$ T-test for independent samples; $\$$ Mann-Whitney test. Source: Authors (2021). 
A significant association of self-harm with suicidal ideation was evidenced, adolescents who practiced self-harm were 14.8 times more likely to experience suicidal ideation, as presented in Table 3.

Table 3 - Association of self-harm with suicidal ideation in adolescents attending a school in a city in southern Minas Gerais, Brazil, 2021.

\begin{tabular}{|c|c|c|c|c|c|c|c|}
\hline \multirow[b]{2}{*}{ Variables } & \multirow[b]{2}{*}{ Present (\%) } & \multicolumn{4}{|c|}{ Self-harm } & \multirow[b]{2}{*}{ OR } & \multirow[b]{2}{*}{ p-value } \\
\hline & & Absent (\%) & Total & \multicolumn{2}{|c|}{ p value $\dagger$} & & \\
\hline Present & $37(97,4)$ & $1(2,6)$ & & 38 & & & \\
\hline Absent & $25(71,4)$ & $10(28,6)$ & & 35 & 0,0024 & 14,8 & 0,0056 \\
\hline Total & 62 & 11 & & 73 & & & \\
\hline
\end{tabular}

Note: $\dagger$ Fisher's Exact test; $\$$ OR: Odds Ratio. The suicidal ideation variable was analyzed using the Children's Depression Inventory. Source: Authors (2021).

The association of suicidal ideation with anxiety and depression scores are presented in Tables 4 and 5, respectively. A significant difference can be found in the scores of participants who did not think about committing suicide (no suicidal ideation) compared to those who expressed this thought but stated that they would not do it, and those who wanted to commit suicide (with suicidal ideation); adolescents experiencing suicidal ideation presented higher anxiety and depression scores.

Table 4- Association of suicidal ideation with anxiety scores in adolescents attending a school in a city in southern Minas Gerais, Brazil, 2021.

\begin{tabular}{|c|c|c|c|c|c|c|c|c|c|}
\hline \multicolumn{10}{|c|}{ Anxiety } \\
\hline \multirow[b]{2}{*}{ Variables } & \multirow[b]{2}{*}{$\begin{array}{l}\text { Mean } \\
\text { scores }\end{array}$} & \multicolumn{3}{|c|}{ Mean positions } & \multicolumn{5}{|c|}{ Dunn's method comparisons } \\
\hline & & R1 & $\mathbf{R 2}$ & $\mathbf{R 3}$ & $\begin{array}{l}\text { Differ } \\
\text { betwe } \\
\text { positio } \\
\end{array}$ & & calculated $\mathrm{z}$ & $\begin{array}{c}\text { critical } \\
\mathbf{z}\end{array}$ & $p$-value \\
\hline $\begin{array}{l}\text { I do not think } \\
\text { about } \\
\text { committing } \\
\text { suicide } \\
\text { n=35 }\end{array}$ & 38,40 & & & & 1 e 2 & 15,10 & 2,88 & 2,39 & $<0,05$ \\
\hline $\begin{array}{l}\text { I think about } \\
\text { it, but I } \\
\text { would not do } \\
\text { it } \\
\text { n=31 }\end{array}$ & 53,38 & 28,47 & 43,58 & $\mathbf{5 0 , 5 0}$ & 1 e 3 & 22,02 & 2,50 & 2,39 & $<0,05$ \\
\hline $\begin{array}{l}\text { I want to } \\
\text { commit } \\
\text { suicide } \\
n=7\end{array}$ & 58,42 & & & & 2 e 3 & 6,91 & 0,77 & 2,39 & ns \\
\hline
\end{tabular}

Note: p: significance level; ns: non-significant; Kruskal-Wallis test. Source: Authors (2021). 
Table 5 - Association of suicidal ideation with depression scores in adolescents attending a school in a city in southern Minas Gerais, Brazil, 2021.

\begin{tabular}{|c|c|c|c|c|c|c|c|c|c|}
\hline \multirow[b]{3}{*}{ Variables } & \multirow[b]{3}{*}{$\begin{array}{l}\text { Mean } \\
\text { scores }\end{array}$} & \multicolumn{7}{|c|}{ Depression } & \\
\hline & & \multicolumn{3}{|c|}{ Mean positions } & \multicolumn{5}{|c|}{ Dunn's method comparisons } \\
\hline & & R1 & $\mathbf{R} 2$ & $\mathbf{R 3}$ & $\begin{array}{r}\text { Diffe } \\
\text { bet } \\
\text { pos }\end{array}$ & $\begin{array}{l}\text { ence } \\
\text { een } \\
\text { ions }\end{array}$ & calculated $\mathrm{z}$ & $\begin{array}{c}\text { critical } \\
\mathbf{z}\end{array}$ & $p$-value \\
\hline $\begin{array}{l}\text { I do not think } \\
\text { about } \\
\text { committing } \\
\text { suicide } \\
\mathrm{n}=35\end{array}$ & 11,8 & & & & 1 e 2 & 18,69 & 3,57 & 2,39 & $<0,05$ \\
\hline $\begin{array}{l}\text { I think about } \\
\text { it, but I would } \\
\text { not do it } \\
n=31\end{array}$ & 20,0 & 25,38 & 44,08 & 63,71 & 1 e 3 & 38,32 & 4,36 & 2,39 & $<0,05$ \\
\hline $\begin{array}{l}\text { I want to } \\
\text { commit } \\
\text { suicide } \\
\mathbf{n}=7\end{array}$ & 31,7 & & & & 2 e 3 & 19,63 & 2,21 & 2,39 & ns \\
\hline
\end{tabular}

Note: p: significance level; ns: non-significant; Kruskal-Wallis test. Source: Authors (2021).

\section{Discussion}

The incidence of self-harm found in the present study was $84.9 \%$, a proportion higher than that found in the literature (Carvalho et al., 2017; Fonseca et al., 2018; Monto et al., 2018; Santos et al., 2020; Swannell et al., 2014). It should be noted that the studies that have been used to investigate self-harm are quite heterogeneous regarding the instruments applied and diagnostic criteria (Cipriano et al., 2017; Taylor et al., 2018), it is inferred that the rates of self-harm incidence are divergent and should be interpreted with caution.

It is believed that the high percentage found in the present study may be related to the epidemic nature of self-harm displayed on the internet, through websites (Otto \& Santos, 2016) and in the school and university settings (Whitlock et al., 2006), allowing the dissemination and disclosure of this behavior (Otto \& Santos, 2016). However, given the economic, cultural, and regional characteristics of the adolescents in the present study, further research is needed to better understand this variable.

Adolescence is identified as a risk period for self-harm behavior with the onset occurring from 13 to 15 years (Glenn \& Klonsky, 2009; Hawton et al., 2013; Nock et al., 2004; Zetterqvist, 2015), these data converge with those of the present study. Self-harm during adolescence is considered a visible marker of emotional and behavioral issues that generate negative psychosocial consequences throughout life (Borschmann et al., 2017).

The adolescents participating in the present study reported feeling little or no pain (58\%), such data differs from a survey assessing the experience of pain during self-harm in which $62 \%$ of participants reported feeling pain during self-harm frequently and $36 \%$ felt it sometimes, and only one participant reported feeling no pain at all (Selby et al., 2019).

According to DeAngelis (2015), self-harm is related to a phenomenon called pain relief, an unpleasant physical reaction to an initial painful stimulus, but over time and with repetition of this stimulus the pain reaction becomes less evident and the self-harm behavior becomes more frequent.

The present study's findings regarding the methods of self-harm reported by adolescents resemble a survey carried out in Serbia in which the most common methods of self-harm among adolescents were cutting, biting, and strong scratching 
(Kostić et al., 2019). According to Carvalho et al. (2017) adolescents opt for quicker types of self-harm that are less judgemental without the need to wait for an opportunity to have sharp instruments at their availability and accessible thus bringing relief from the emotional suffering that afflicts them so heavily.

The motivations reported by the adolescents in this study for the practice of self-harm corroborate a study carried out in the school context of a city in Minas Gerais, Brazil (Fonseca et al., 2018). Intrapersonal functions, mostly those related to emotional regulation and search for relief from negative feelings (Raupp et al., 2018; Taylor et al., 2018), control of thoughts and distress, through escape, avoidance, replacement, or modification of these emotions are related to the motivation of the practice for self-harm behavior (Taylor et al., 2018).

The self-harm behavior found in this study was more prevalent in females, which is in line with other studies (Fonseca et al., 2018; Monto et al., 2018), and they are also more likely to report at least one self-harm incident (Monto et al., 2018). One in three females has practiced self-harm at least once between the ages of 13 and 20, while for males this number was one in five. Furthermore, it is noteworthy that there are considerable gender differences in the course of self-harm over time (Steinhoff et al., 2020).

Cultural and family behavioral rules and norms of obedience and respect are related to self-harm, including social and religious oppression and exploitative discrimination, especially toward girls. In addition, girls tend to take more responsibility for household chores, care for other family members, are more subject to sexual abuse and exploitation, exclusion from education and decision-making, and unemployment (Quarshie et al., 2020).

In the present study, $37.1 \%$ of the adolescents who practiced self-harm reported suicidal ideation and presented higher anxiety and depression scores. Those with suicidal ideation also presented higher anxiety and depression scores. A higher proportion of suicidal ideation was found in a survey that investigated the intention of practicing self-harm among young Latinas aged between 11 and 19 years, where $52.7 \%$ of the adolescents performed self-harm with suicidal intent (Gulbas et al., 2015).

Self-harm is considered a marker of mental disorder severity and can be used in predicting suicide attempts (Kiekens et al., 2018), it is also associated with depression, anxiety, and post-traumatic stress disorder (American Psychiatric Association, 2014; Bentley et al., 2014; Izadi-Mazidi et al., 2019; Wasserman, 2016). Adolescents who have practiced selfharm present higher scores of suicidal ideation and stronger associations with depression, shame, self-criticism, stress, and anxiety (Carvalho et al., 2017).

Self-harm is a concerning behavior, over time it may take less effort from individuals to perform it, and it may become a chronic behavior due to its recurring nature (Liu, 2017).

The prevalence of suicidal behavior is high among adolescents (Simões et al., 2019) and it is a serious public health issue that is among the leading causes of death in this group (World Health Organization, 2020). It is noteworthy that depression, which peaks during adolescence, is an important risk factor for suicide (Salk et al., 2017), and that the rate of suicidal ideation among adolescents suffering from depression is higher (Avenevoli et al., 2015; Tarlow et al., 2019), and it is also related to anxiety (Biswas et al., 2020), which is in line with the present study's findings.

In a global study carried out with adolescents aged between 13 and 19, it was found that the overall prevalence of suicidal ideation was 16.9\%, suicide planning and attempts were 17.0\% (Uddin et al., 2019). An increase in the occurrence of suicide among adolescents is observed which can generate negative consequences for both the victim's family and social circle (Moreira \& Bastos, 2015).

In Brazil, the rate of suicidal ideation among adolescents is high, which may be related to the high exposure to risk factors they are subject to (family history of suicide, mental health changes such as depression, exposure to violence, use of alcohol, and other drugs, and family issues) (Moreira \& Bastos, 2015). 
The WHO recognizes suicide prevention as a public health priority (World Health Organization, 2014), and guides the implementation of a surveillance system for suicide attempts and self-harm in order to improve the quality of data that can assist in guiding and prioritizing interventions and contribute to the implementation of effective strategies for suicide prevention (World Health Organization, 2016). In addition, initiatives aimed at providing suicide prevention are necessary and should consider the cultural and socioeconomic backgrounds of the country in question (Uddin et al., 2019).

\section{Conclusion}

High rates of self-harm behavior (84.9\%) were found in this study, the main motivations for practicing self-harm are related to the regulation of one's emotions, self-harm is associated with suicidal ideation, depression, and anxiety, and adolescents with suicidal ideation presented higher anxiety and depression scores. Regarding gender, girls presented a higher proportion of self-harm.

It is worth noting that $37.1 \%$ of the participants were thinking of committing suicide when they were practicing selfharm, a fact that deserves attention as it is a risk factor for suicide. Moreover, the practice of this behavior generates significant suffering and can interfere negatively in their lives.

The need for more attention to the mental health of adolescents in the school context is highlighted, such as the training of education professionals to identify risk factors for self-harm behavior, the implementation of strategic and multisectoral actions including education and health professionals, along with family members.

Therefore, it is essential to consolidate more effective public policies, which go beyond health institutions, aimed at promoting mental health for adolescents in the school setting, which is one of the places where adolescents spend most of their time.

Carrying out further studies that validate the self-harm scale used in this study for the Brazilian population in the various contexts in which adolescents are inserted and that aim to better understand gender differences regarding self-harm is suggested. Furthermore, studies that implement interventional strategies that support adolescents in the regulation of their emotions, that contribute to the promotion of mental health and the reduction of self-harm behavior are relevant.

\section{References}

American Psychiatric Association (2014). Manual Diagnóstico e Estatístico de Transtornos Mentais (5th ed.). Artmed.

Avenevoli, S., Swendsen, J., He, J.-P., Burstein, M., \& Merikangas, K. (2015). Major Depression in the National Comorbidity Survey- Adolescent Supplement: Prevalence, Correlates, and Treatment Shelli. J Am Acad Child Adolesc Psychiatry, 1(54), 37-44.e2. https://doi.org/10.1016/j.jaac.2014.10.010.Major

Barbosa, G. A., Barbosa, A. G., \& Gouveia, V. V. (2002). Transtorno de Ansiedade na infância e adolescência: um estudo de prevalência e validação de um instrumento (SCARED) de triagem. Infanto- Revista Neuropsiquiatria Da Infância e Adolescência, 1(10), $34-47$.

Bentley, K. H., Nock, M. K., \& Barlow, D. H. (2014). The four-function model of nonsuicidal self-injury: Key directions for future research. Clinical Psychological Science, 2(5), 638-656. https://doi.org/10.1177/2167702613514563

Biswas, T., Scott, J. G., Munir, K., Renzaho, A. M. N., Rawal, L. B., Baxter, J., \& Mamun, A. A. (2020). Global variation in the prevalence of suicidal ideation, anxiety and their correlates among adolescents: A population based study of 82 countries. EClinicalMedicine, 24 , 100395. https://doi.org/10.1016/j.eclinm.2020.100395

Borschmann, R., Becker, D., Coffey, C., Spry, E., Moreno-Betancur, M., Moran, P., \& Patton, G. C. (2017). 20-Year Outcomes in Adolescents Who SelfHarm: a Population-Based Cohort Study. The Lancet Child and Adolescent Health, 1(3), 195-202. https://doi.org/10.1016/S2352-4642(17)30007-X

Brazilian Association of Research Companies (2016). Brazilian Economic Classification Criteria. Retrieved Jan 6, 2022, from http://www.abep.org/criteriobrasil.

Carvalho, C. B., da Motta, C., Sousa, M., \& Cabral, J. (2017). Biting myself so I don't bite the dust: Prevalence and predictors of deliberate self-harm and suicide ideation in azorean youths. Revista Brasileira de Psiquiatria, 39(3), 252-262. https://doi.org/10.1590/1516-4446-2016-1923

Cipriano, A., Cella, S., \& Cotrufo, P. (2017). Nonsuicidal self-injury: A systematic review. Frontiers in Psychology, 8, 1-14. https://doi.org/10.3389/fpsyg.2017.01946 
Coutinho, M. da P. de L., Oliveira, M. X. De, \& Pereira, D. R. (2014). Psychometric Indicators of Children's Depression Inventory and Childhood Sample. Avaliação Psicológica, 13(2), 269-276. Retrieved Jan 6, 2022, from http://pepsic.bvsalud.org/pdf/avp/v13n2/v13n2a14.pdf

DeAngelis, T. (2015). A new look at self-injury. American Psychological Association. https://www.apa.org/monitor/2015/07-08/self-injury

Fonseca, P. H. N. da, Silva, A. C., Araújo, L. M. C., \& Botti, N. C. L. (2018). Non-suicidal self-injury intent among adolescents. Arquivos Brasileiros de Psicologia, 70(3), 246-258. Retrieved Jan 6, 2022, from http://pepsic.bvsalud.org/scielo.php?script=sci_arttext\&pid=S180952672018000300017

Fortes, I., \& Macedo, M. M. K. (2017). Self-mutilation in adolescence - scratches in the otherness experience. Psicogente, 20 (38), 353-367. http://doi.org/10.17081/psico.20.38.2556

Geulayov, G., Casey, D., Bale, L., Brand, F., Clements, C., Farooq, B., Kapur, N., Ness, J., Waters, K., Tsiachristas, A., \& Hawton, K. (2019). Suicide following presentation to hospital for non-fatal self-harm in the Multicentre Study of Self-harm: a long-term follow-up study. The Lancet Psychiatry, 6(12), 1021-1030. https://doi.org/10.1016/S2215-0366(19)30402-X

Giusti, J. S. (2013). Automutilação: características clínicas e comparação com pacientes com transtorno obsessivo-compulsivo. [Tese de Doutorado, Universidade de São Paulo, São Paulo, Brasil]. Retrieved Jan 6, 2022, from http://www.teses.usp.br/teses/disponiveis/5/5142/tde-03102013-113540/pt-br.php

Glenn, C. R., \& Klonsky, E. D. (2009). Social context during non-suicidal self-injury indicates suicide risk. Personality and Individual Differences, 46(1), 2529. https://doi.org/10.1016/j.paid.2008.08.020

Gouveia, V. V., Barbosa, G. A., Almeida, G. J. F. de, \& Gaião, A. de A. (1995). Child depression inventory - CDI: adaptation study with students from Joao Pessoa. Jornal Brasileiro de Psiquiatria, 345-349.

Gulbas, L. E., Hausmann-Stabile, C., De Luca, S. M., Tyler, T. R., \& Zayas, L. H. (2015). An exploratory study of nonsuicidal self-injury and suicidal behaviors in adolescent latinas. American Journal of Orthopsychiatry, 85(4), 302-314. https://doi.org/10.1037/ort0000073

Hawton, K., Bergen, H., Cooper, J., Turnbull, P., Waters, K., Ness, J., \& Kapur, N. (2015). Suicide following self-harm: Findings from the Multicentre Study of self-harm in England, 2000-2012. Journal of Affective Disorders, 175, 147-151. https://doi.org/10.1016/j.jad.2014.12.062

Hawton, K., Saunders, K., Topiwala, A., \& Haw, C. (2013). Psychiatric disorders in patients presenting to hospital following self-harm: A systematic review. Journal of Affective Disorders, 151(3), 821-830. https://doi.org/10.1016/j.jad.2013.08.020

Hooley, J. M., Fox, K. R., \& Boccagno, C. (2020). Nonsuicidal self-injury: Diagnostic challenges and current perspectives. Neuropsychiatric Disease and Treatment, 16, 101-112. https://doi.org/10.2147/NDT.S198806

Izadi-Mazidi, M., Yaghubi, H., Mohammadkhani, P., \& Hassanabadi, H. (2019). Assessing the functions of non-suicidal self-injury: Factor analysis of functional assessment of self-mutilation among adolescents. Iranian Journal of Psychiatry, 14(3), 184-191. https://doi.org/10.18502/ijps.v14i3.1319

Kiekens, G., Hasking, P., Boyes, M., Claes, L., Mortier, P., Auerbach, R. P., Cuijpers, P., Demyttenaere, K., Green, J. G., Kessler, R. C., Myin-Germeys, I., Nock, M. K., \& Bruffaerts, R. (2018). The associations between non-suicidal self-injury and first onset suicidal thoughts and behaviors. Journal of Affective Disorders, 239, 171-179. https://doi.org/10.1016/j.jad.2018.06.033

Kostić, J., Žikić, O., Stankovic, M., \& Nikolić, G. (2019). Nonsuicidal self-injury among adolescents in south-east Serbia. International Journal of Pediatrics and Adolescent Medicine, 6(4), 131-134. https://doi.org/10.1016/j.ijpam.2019.06.002

Law n $\mathrm{n}^{\circ}$ 13.819, de 26 de abril de 2019.Institui a Política Nacional de Prevenção da Automutilação e do Suicídio, a ser implementada pela União, em cooperação com os Estados, o Distrito Federal e os Municípios; e altera a Lei $n^{o}$ 9.656, de 3 de junho de 1998. Retrieved Jan 6, 2022, from https://www.in.gov.br/web/dou/-/lei-n\%C2\%BA-13.819-de-26-de-abril-de-2019-85673796

Liu, R. T. (2017). Characterizing the course of non-suicidal self-injury: A cognitive neuroscience perspective. Neuroscience and Biobehavioral Reviews, 80, 159-165. https://doi.org/10.1016/j.neubiorev.2017.05.026

Lloyd, E. E. (1997). Self-Mutilation in a Community Sample of Adolescents. [Dissertation, Louisiana State University, Louisiana, United States]. Retrieved Jan 6, 2022, from https://digitalcommons.lsu.edu/gradschool_disstheses/6546/

Monto, M. A., McRee, N., \& Deryck, F. S. (2018). Nonsuicidal self-Injury among a representative sample of US adolescents, 2015. American Journal of Public Health, 108(8), 1042-1048. https://doi.org/10.2105/AJPH.2018.304470

Moreira, L. C. de O., \& Bastos, P. R. H. de O. (2015). Prevalence and risk factors associated with suicidal ideation in adolescents: literature review. Revista Quadrimestral Da Associação Brasileira de Psicologia Escolar e Educacional, 19(3), 445-453. https://doi.org/10.1590/2175-3539/2015/0193857

National Health Council (2013). National Human Research Ethics Committee. Resolution no. 466/12. Regulatory Guidelines and Norms for Research Developing Humans. Brasília, DF, Brazil. Retrieved Jan 6, 2022, from https://conselho.saude.gov.br/resolucoes/2012/466_english.pdf.

Nock, M. K., \& Prinstein, M. J. (2004). A functional approach to the assessment of self-mutilative behavior. Journal of Consulting and Clinical Psychology, 72(5), 885-890. https://doi.org/10.1037/0022-006X.72.5.885

Otto, S. C., \& Santos, K. A. dos. (2016). O Tumblr e sua relação com práticas autodestrutivas : o caráter epidemico da autolesão. Psic. Rev. São Paulo, 25(2), 265-288. Retrieved Jan 6, 2022, from https://revistas.pucsp.br/index.php/psicorevista/article/view/24537

Owens, D., Horrocks, J., \& House, A. (2002). Fatal and non-fatal repetition of self-harm. British Journal of Psychiatry, 181(3), 193-199. https://doi.org/10.1192/bjp.181.3.193

Quarshie, E. N. B., Waterman, M. G., \& House, A. O. (2020). Self-harm with suicidal and non-suicidal intent in young people in sub-Saharan Africa: A 
systematic review. BMC Psychiatry, 234(20), 1-26. https://doi.org/10.1186/s12888-020-02587-z

Raupp, C. S., Marin, A. H., \& Mosmann, C. P. (2018). Self-harming behavior and emotional management in female adolescents. Psic.Clin., 30(2), 209-308. http://dx.doi.org/10.33208/PC1980-5438v0030n02A05

Rodrigues-Palucci, C. M., \& Loureiro, S. R. (2017). Indicators of problems evaluated by parents and children stratified by birth weight crianças estratificadas pelo peso ao nascer. Estudos de Psicologia, 34(1), 107-118. https://doi.org/10.1590/1982-02752017000100011

Salk, R. H., Hyde, J. S., \& Abramson, L. Y. (2017). Gender Differences in Depression in Representative National Samples: Meta-Analyses of Diagnoses and Symptoms. Psychol Bull., 143(8), 783-822. https://doi.org/10.1037/bul0000102.Gender

Santos, J. H., Pires, C. F., Pereira, D. M., \& Silva, D. L. (2020). Self-injurious behaviors in public school adolescents. Adolescencia e Saude, $17(2)$, 34-41.

Selby, E. A., Kranzler, A., Lindqvist, J., Fehling, K. B., Brillante, J., Yuan, F., Gao, X., \& Miller, A. L. (2019). The Dynamics of Pain During Nonsuicidal Self-Injury. Clinical Psychological Science, 7(2), 302-320. https://doi.org/10.1177/2167702618807147

Simões, R. M. P., Santos, J. C. P., \& Martinho, M. J. C. M. (2019). Effectiveness of psychotherapeutic interventions targeted at adolescents with suicidal behavior: an integrative literature review. Journal of Nursing Referência , 20(5), 139-148. https://doi.org/10.12707/RIV18027

Steinhoff, A., Ribeaud, D., Kupferschmid, S., Raible-Destan, N., Quednow, B. B., Hepp, U., Eisner, M., \& Shanahan, L. (2020). Self-injury from early adolescence to early adulthood: age-related course, recurrence, and services use in males and females from the community. European Child and Adolescent Psychiatry, 30(6), 937-951. https://doi.org/10.1007/s00787-020-01573-w

Swannell, S. V., Martin, G. E., Page, A., Hasking, P., \& St John, N. J. (2014). Prevalence of nonsuicidal self-injury in nonclinical samples: Systematic review, meta-analysis and meta-regression. In Suicide and Life-Threatening Behavior (Vol. 44, Issue 3, pp. 273-303). Wiley-Blackwell. https://doi.org/10.1111/sltb.12070

Tarlow, K. R., Johnson, T. A., \& McCord, C. E. (2019). Rural Status, Suicide Ideation, and Telemental Health: Risk Assessment in a Clinical Sample. Journal of Rural Health, 35(2), 247-252. https://doi.org/10.1111/jrh.12310

Tavares, B. F., Béria, J. U., \& Lima, M. S. de. (2004). Fatores associados ao uso de drogas entre adolescentes escolares. Rev Saúde Pública, $38(6)$, 787-796.

Taylor, P. J., Jomar, K., Dhingra, K., Forrester, R., Shahmalak, U., \& Dickson, J. M. (2018). Journal of A ff ective Disorders Review article A meta-analysis of the prevalence of di ff erent functions of non-suicidal self- injury. Journal of Affective Disorders, 227, 759-769. https://doi.org/10.1016/j.jad.2017.11.073

Uddin, R., Burton, N. W., Maple, M., Khan, S. R., \& Khan, A. (2019). Suicidal ideation, suicide planning, and suicide attempts among adolescents in 59 lowincome and middle-income countries: a population-based study. The Lancet Child and Adolescent Health, 3(4), 223-233. https://doi.org/10.1016/S23524642(18)30403-6

Wasserman, D. (2016). Review of health and risk-behaviours, mental health problems and suicidal behaviours in Young europeans on the basis of the results from the eu-funded Saving and Empowering Young Lives in Europe (SEYLE) study. Psychiatria Polska, 50(6), 1093-1107. https://doi.org/10.12740/PP/66954

Whitlock, J., Eckenrode, J., \& Silverman, D. (2006). Self-injurious behaviors in a college population. Pediatrics, 117(6), 1939-1948. https://doi.org/10.1542/peds.2005-2543

World Health Organization. (2014). Preventing suicide: a global imperative. Retrieved Jan 6, 2022, from https://www.paho.org/en/documents/preventingsuicide-global-imperative

World Health Organization. (2016). Practice manual for establishing and maintaining surveillance systems for suicide attempts and self-harm. Retrieved Jan 6 , $2022, \quad$ from https://apps.who.int/iris/bitstream/handle/10665/208895/9789241549578_eng.pdf;jsessionid=5A3D7C8C2A3C5F61C4E9F326033BA2BE?sequence=1

World Health Organization (2020). Adolescent mental health. Retrieved Jan 6, 2022, from https://www.who.int/news-room/fact-sheets/detail/adolescentmental-health

Zetterqvist, M. (2015). The DSM-5 diagnosis of nonsuicidal self-injury disorder: A review of the empirical literature. Child and Adolescent Psychiatry and Mental Health, 9(31), 1-13. https://doi.org/10.1186/s13034-015-0062-7 